\title{
NOVI NEMŠKO-SLOVENSKI SLOVAR
}

Z nemško-slovenski slovar, ki ga je pripravil pravnik, prevajalec in publicist Igor Antič. Slovar ima 531 strani in 42.000 gesel, spada torej med slovarje srednjega obsega.

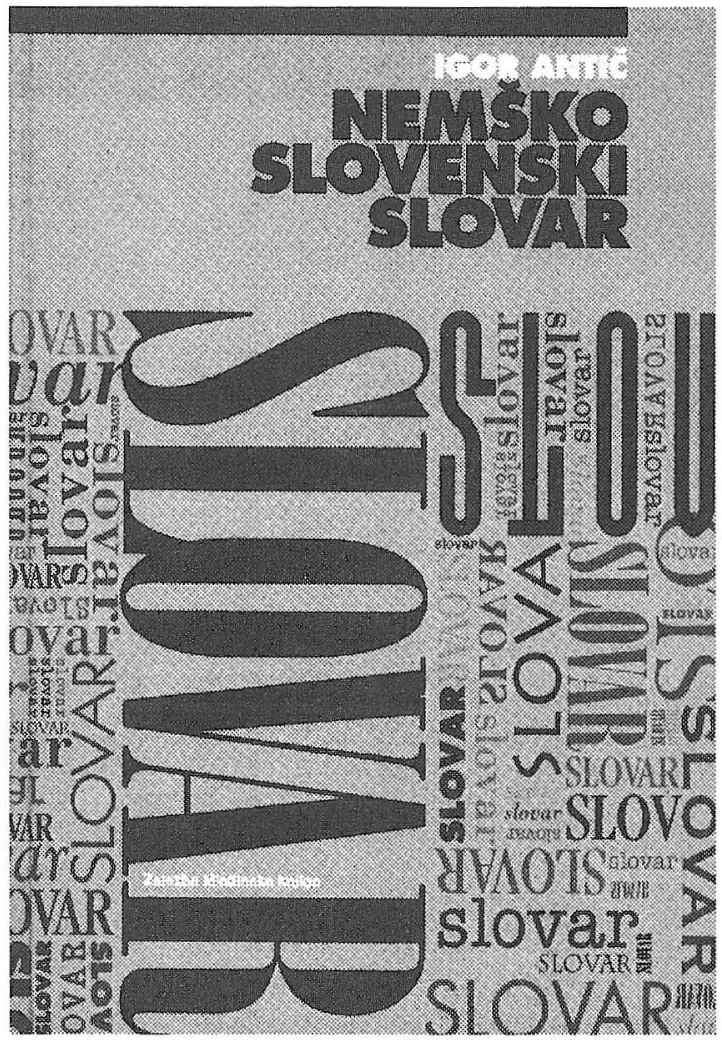

Leksikografsko zasnovo in jezikovni pregled sta opravili dr. Alenka $\mathrm{Vr}$ binc in $\mathrm{dr}$. Marjeta Vrbinc.

Čeprav smo kot majhen narod obsojeni na to, da moramo že od nekdaj sami strokovno in finančno skrbeti za pripravo in izdajo dvojezičnih slovarjev, imamo dolgo tradicijo izdajanja nemškoslovenskih in slovensko-nemških slovarjev: od Cigaleta (1860) in Pleteršnika (1894/1895) pa do znanega Tomšičevega slovarja (1975) in najnovejših izdaj. Da se boste lažje in pravilneje odločili za nakup, bomo Antičev slovar na kratko primerjali z Debenjakovim nemško-slovenskim slovarjem (DZS, 1992) in Gradišnikovim
Nemško-slovenskim in slovensko-nemškim v eni knjigi (Založba Obzorja, 1997), in sicer predvsem $z$ vidika jezikovno povprečno izobraženega uporabnika, ne jezikoslovca ali prevajalca, ki ima drugačne zahteve in ki drugače razume jezik.

V obširnem in preglednem uvodu izvemo, da ima na novo sestavljen geslovnik, ki poleg besed iz vsakdanjega življenja zajema tudi pojme iz računalništva, telekomunikacij in politične strukture Evropske unije, najdemo pa tudi nove izraze s področja športa in turizma, tehnike, varstva okolja, informatike in bančništva ter številne okrajšave. Prilagojen je uporabniku, čigar materni jezik je slovenščina (v slovenščini so poleg uvoda vse slovnične, področne in slogovne oznake $v$ geslih), zato ni potrebno poznavanje nemških slovničnih terminov, ki jih uporablja Debenjakov slovar. Antičev slovar je sestavljen po pravilih novega nemškega pravopisa, ki je začel veljati 1. avgusta 1998 , zato smo lahko upravičeno ponosni, da gremo v korak $s$ časom tudi na tem področju. O poglavitnih značilnostih novega pravopisa se lahko poučimo v dodatku k slovarju. Ker ni tako obsežen kot Debenjakov slovar, ki vsebuje kar 120.500 gesel, ima večje črke in je zato uporabniku prijaznejši, posamezna gesla pa so (predvsem navajajo številne praktične zglede rabe) $\mathrm{v}$ primerjavi $\mathrm{z}$ Gradišnikovim slovarjem, ki je prostorsko omejen zaradi dvosmernega slovarja v eni knjigi, obširnejša.

V Debenjakovem in Gradišnikovem slovar- 
ju je zelo malo pojasnil o posebnostih slovničnih oblik - na primer ni oblik za preterit in perfekt s pomožnim glagolom pri nepravilnih glagolih, pa tudi ne nepravilnih oblik $\mathrm{v}$ sedanjiku, končnic za rodilnik in množino pri sestavljenih samostalnikih, nepravilno stopnjevanih oblik primernika in presežnika pri pridevnikih in sklona pri predlogih, tako kot v Antičevem slovarju. V Debenjakovem slovarju so nepravilni glagoli označeni le z zvezdico, v Gradišnikovem pa jih je treba poiskati v sicer obširnem seznamu nepravilnih glagolov na začetku slovarja, vendar v geslu samem ni opozorila, da gre za nepravilni glagol.

Prednost Antičevega slovarja je tudi ta, da je pri vseh besedah, ki jih ne izgovarjamo po splošno znanih pravilih, dodan zapis izgovorjave, prilagojen slovenskemu uporabniku. To vija predvsem za tujke. Pri tem je tudi označeno, ali se v Avstriji ali Švici beseda drugače izgovarja. V Debenjakovem slovarju podatkov o izgovorjavi ni, v Gradišnikovem pa le redko. Zelo koristne so oznake, da imajo nekateri samostalniki v Avstriji ali Švici drugačno obliko (na primer množino ali rodilnik ednine) ali drugačen pomen. Teh kvalifikatorjev Debenjakov slovar žal nima.

Razveseljivo je, da je Igor Antič pri tujkah, ki jih imamo tudi v slovenščini, dodal slovensko ustreznico, čeprav se mu vselej to ni najbolje posrečilo (na primer za »Mietwagen « najdemo v Debenjakovem slovarju pojasnilo »najemno vozilo, najemni voz, taksi, izvošček «, v Antičevem pa »vozilo v najemu «, čeprav gre preprosto za najeto vożilo). V Debenjakovem slovarju namreč kar mrgoli tujk $\mathrm{v}$ slovenskih prevodih, čeprav imamo lepši ali enakovreden slovenski izraz. Tako moramo uporabiti še Slovar slovenskega knjižnega jezika, v katerem najdemo za tujko boljšo ustreznico. Nekaj primerov:

\begin{tabular}{|c|c|c|}
\hline Nemški izraz & Debenjakov slovar & Antičev slovar \\
\hline deklarieren & deklarirati & deklarirati, izjaviti; prïjaviti (na carini) \\
\hline delikot & delikaten & delikaten, nežen, obcuutlijv, kocdjiv \\
\hline delogieren & deložrirati & deložirati, prisilno izselifi \\
\hline Denunziation, die & denunciacija & denunciacija, ovadba \\
\hline Mindestabstand, der & minimalna oddaljenost & najmanijsi odmik, naimanišsa razdalja \\
\hline Plagiator, der & plagiator & plagiator, prepisovalec \\
\hline Pointe, die & poanta & poanta, jedro, učinek \\
\hline Polygamie, die & poligamija & poligamija, mnogoženstvo, mnogomoštvo \\
\hline pompös & pompozen & pompozen, razkosen, sijpjen, hrupen \\
\hline
\end{tabular}

Včasih pa je prevod v obeh slovarjih neustrezen: na primer »pflegeleicht « je v Debenjakovem in Antičevem slovarju prevedeno kot »lahek za vzdrževanje « - ustrezneje je »preprost za vzdrževanje, ki se preprosto vzdržuje«. Včasih najdemo ustreznejši prevod v Debenjakovem slovarju: na primer za »Ministerpräsident « ima Debenjak ustreznico »predsednik vlade «, Antič pa »ministrski predsednik «. Pogosto je v Debenjakovem slovarju najti več zgledov uporabe, kar glede na obsežnost slovarja tudi pričakujemo, na primer za »Missbrauch « ima Antič le ustreznico »zloraba «, Debenjak pa navaja tudi, s katerimi izrazi ga najpogosteje povezujemo (von Schlafmitteln, Nikotin , Tabletten , der Amtsgewalt). Seveda ima Debenjakov slovar v primerjavi z Antičevim večinoma tudi več gesel s temeljno besedo (na primer s temeljno besedo »Miete « ima Debenjak 31 gesel, Antič pa 8, s temeljno besedo "Millitär « ima Debenjak 43 sestavljenk, Antič pa 14), čeprav bi v zvezi s sodobnimi izrazi lahko to pričakovali tudi od Antičevega slovarja. Pogrešamo tudi več stalnih besednih zvez ali frazeoloških izrazov, saj le-ti manj veščemu uporabniku nemškega jezika povzročajo pri razumevanju in uporabi nemščine številne težave.

Novi Antičev Nemško-slovenski slovar ima torej prednosti in tudi nekaj slabosti. Priporočam ga predvsem tistim uporabnikom nemškega jezika, ki nimajo zelo dobrega znanja nemške slovnice in slovnične termi- 
nologije in ki ne iščejo posebnih izrazov. Če si boste ogledali še navodila za uporabo, se boste pri uporabi slovarja zelo hitro in dobro znašli. Prav gotovo ima nekaj prednosti v primerjavi z Velikim nemško-slovenskim slovarjem družine Debenjak in obojestranskim Gradišnikovim slovarjem, včasih pa nam bo pri iskanju slovenskih ustreznic še najbolj pomagala uporaba dveh ali treh slovarjev. Temu se pogosto ne da izogniti, le pri roki jih nimamo vselej.

Poleg Velikega nemško-slovenskega slovarja družine Debenjak, ki je izšel leta 1992 pri DZS, in nove izdaje Gradišnikovega Nemško-slovenskega in slovensko-nemške- ga slovarja v eni knjigi (Založba Obzorja Maribor, 1997) imamo sedaj slovar srednjega obsega, ki upošteva novi nemški pravopis. Letošnjo bogato slovarsko bero dvojezičnih nemško-slovenskih slovarjev pa dopolnjujeta še novi Mali nemško-slovenski slovar Katje Berden, ki je izšel pri založbi DZS, in - prava novost na našem tržišču Slovenski pravni leksikon $\mathrm{z}$ nemškimi in italijanskimi ustreznicami geselskih besed, ki ga je izdal OST - svetovalne storitve v sodelovanju $\mathrm{z}$ Društvom znanstvenih in tehniških prevajalcev Slovenije. 